\title{
The Importance of the Training-Induced Decrease in Basal Cortisol Concentration in the Improvement in Muscular Performance in Humans
}

\author{
M. GRANDYS ${ }^{1}$, J. MAJERCZAK ${ }^{1}$, J. KULPA ${ }^{2}$, K. DUDA ${ }^{3}$, U. RYCHLIK ${ }^{2}$, J. A. ZOLADZ ${ }^{1}$ \\ ${ }^{1}$ Department of Muscle Physiology, Chair of Physiology and Biochemistry, Faculty of \\ Rehabilitation, University School of Physical Education, Krakow, Poland, ${ }^{2}$ Department of Clinical \\ Biochemistry, Cancer Institute, Krakow, Poland, ${ }^{3}$ Institute of Health Care, State Higher Vocational \\ School in Tarnow, Tarnow, Poland
}

Received March 16, 2015

Accepted August 28, 2015

On-line November 24, 2015

\section{Summary}

Acute exercise-induced changes in cortisol concentration (C) and training related adaptation within hypothalamic-pituitary-adrenal (HPA) axis has been widely examined, but their influence on muscle strength performance is at best uncertain. Twenty four young healthy men were randomly assigned to an endurance training group ( $\mathrm{ET}, \mathrm{n}=12$ ) or to a non-exercising controls (CON, $\mathrm{n}=12$ ). ET performed supervised endurance training on cycle ergometer for 20 weeks. Endurance training program improved exercise capacity (14\% increase in power output generated at peak oxygen uptake $\left.-\mathrm{VO}_{2 \text { peak }}\right)$, muscle strength performance (increase in MVC - maximal voluntary contraction - by $9 \%$ and in TTF $50 \%$ MVC - time to fatigue at $50 \%$ MVC - by $21 \%$ ) and led to a decrease in basal serum $C$ concentration $(P=0.006)$ and an increase in basal testosterone to cortisol $(T / C)$ and free testosterone to cortisol (fT/C) ratios ( $P=0.01$ and $P=0.02$, respectively). It was found that the decrease in $C$ concentration $(\Delta C)$ was positively correlated to the increase in local muscular endurance ( $\triangle T T F 50 \% \mathrm{MVC}$ ). No significant hormonal changes were seen in CON group. It is concluded that greater decrease in cortisol concentration after the endurance training is accompanied by poorer improvement in skeletal muscle performance in previously untrained subjects.

\section{Key words}

Glucocorticoids - Testosterone • Strength • Local muscular endurance

\section{Corresponding author}

J. A. Zoladz, Department of Muscle Physiology, Chair of Physiology and Biochemistry, Faculty of Rehabilitation, University School of Physical Education, Al. Jana Pawla II 78, 31-571 Krakow, Poland. Phone/Fax: $48 \quad 12 \quad 683 \quad 13 \quad 16 . \quad$ E-mail: jerzy.zoladz@awf.krakow.pl

\section{Introduction}

Activation of the hypothalamic-pituitary-adrenal (HPA) axis is indispensable for the appropriate regulation of the energetic, metabolic and immunological processes in response to exercise stress (Galbo 1986). Acute and training-induced changes in cortisol (C) concentration and its physiological role has been widely studied (O'Leary and Hackney 2014), and it is known that exercise training leads to exposition to high glucocorticoids concentration, both in animal (de Araujo et al. 2015) and human studies (Hill et al. 2008). It is of great importance, especially in endurance type of training, because prolonged hypercortisolemia may have also adverse effects on different cell functions in humans, e.g. in leading to muscle proteolysis and protein degradation (Schakman et al. 2013), impairment of insulin secretion of beta-cells (van Raalte et al. 2010) and suppression of the nitric oxide system in the endothelium (Liu et al. 2009). These can occur as a consequence of elevated circulating glucocorticoids, but also due to enhanced activity of the glucocorticoid receptor or the 
11ß-hydroxysteroid dehydrogenase type 1 (11ßHSD1), an enzyme that converts cortisone to active cortisol. Moreover, it was demonstrated that the repeated hypercortisolemia may disrupt the negative feedback loop of the HPA axis and results in both basal and exerciseinduced modification in hormonal responses (Luger et al. 1987).

Training-induced changes in $\mathrm{C}$ concentration may also affect muscle performance as it is currently understood that glucocorticoids influence intracellular signaling pathways involved in training adaptation (Schakman et al. 2013). Decrease in the activity of p38 MAPK and PI3K/Akt/mTOR pathway by enhanced $\mathrm{C}$ concentration may have adverse effect on muscle strength performance and conversely, the diminished $\mathrm{C}$ level after a training program seems to create a favorable condition for intracellular pathways that augment muscle protein synthesis and muscle performance. Interestingly, there is no data in the literature on the relationship between training-induced changes in $\mathrm{C}$ concentration and muscle strength performance. This issue is even more complex, because there is also no agreement on the direction of the $\mathrm{C}$ changes during long term training as well as on the mechanism(s) by which these adaptive changes occur.

Basal C concentration has been reported to either increase (Hoogeveen and Zonderland 1996, Kirwan et al. 1988, Seidman et al. 1990) or not change (Bresciani et al. 2011, Grandys et al. 2008, Lehmann et al. 1993) in response to endurance training. It was also demonstrated that heavy endurance training periods in competitive athletes may lead to decreased $\mathrm{C}$ concentration (Lucia et al. 2001) what has been linked to overtraining syndrome (Snyder et al. 1995). Similarly, different results were also presented when basal $\mathrm{C}$ concentrations were compared between endurance-trained athletes and untrained subjects. In some reports, the athletes had higher C concentration (Barron et al. 1985, Luger et al. 1987) and in others its concentration remained similar to the untrained controls (Duclos et al. 2003, Wittert et al. 1996).

In this study we have employed this type of training that is commonly used by millions of people worldwide who are taking part in recreational exercise training (i.e. moderate intensity endurance training). It is well known that high physiological demands of the longterm endurance training program, even at relatively moderate intensities, results in need for closely monitoring the responses of individuals to training load.
Monitoring hormonal changes seems to be especially important in the case of people with subclinical hormonal disturbances who undertake physical exercise training as well as in the case of patients involved in endurance based rehabilitation programs. Therefore, we aimed in this study to determine cortisol concentration and its relationship to muscle performance during well controlled exercise training of moderate intensity. Moreover, we have also assessed other hormonal variables that influence anabolic-catabolic status of the body, i.e. testosterone ( $\mathrm{T}$ ), free testosterone (fT), sex hormone-binding globulin (SHBG) and $\mathrm{T} / \mathrm{C}$ and $\mathrm{fT} / \mathrm{C}$ ratios, as they may serve as an additional tool for monitoring training status.

\section{Methods}

\section{Subjects}

Twenty four young healthy men of mean $( \pm$ SD) age $22.58( \pm 1.35)$ years, height $179.1( \pm 6.91) \mathrm{cm}$, body mass $75.11( \pm 12.47) \mathrm{kg}$ and BMI $23.36( \pm 3.16) \mathrm{kg} \cdot \mathrm{m}^{-2}$, voluntarily recruited students of physiotherapy and tourism and leisure, participated in this study. All students had normal medical histories and were untrained but physically active, non-smoking men (on average, less than $2 \mathrm{~h}$ of physical activity weekly). After a standard medical evaluation and a routine blood tests (Table 2), they were equally and randomly assigned to an endurance training group (ET, $\mathrm{n}=12)$ or to a non-exercising control group $(\mathrm{CON}, \mathrm{n}=12)$. There were no differences between these two groups in age, body height, body mass (BM) and BMI (Table 1). ET group underwent all laboratory and physical performance tests (anthropometrical measurements, incremental exercise test, blood tests and isometric strength and endurance testing), whereas CON were subjected only to basic anthropometric measurements and blood testing in order to exclude a potential influence of seasonal variation on hormone concentrations examined in this study. Each group of subjects was tested twice, at 20-week interval, i.e. before and after endurance training in ET group and before and after control period in $\mathrm{CON}$ group.

All subjects were fully informed about the aims and experimental procedures of this study and gave written consent to participate before entering the study. The authors obtained approval for this investigation from the Local Ethical Committee and the study protocol was conducted in accordance to the Declaration of Helsinki. 
Table 1. Basic anthropometric characteristics of the students from endurance training group (ET) and control group (CON) at inclusion to the study.

\begin{tabular}{lcccc}
\hline & $\begin{array}{c}\text { Age } \\
(\text { years })\end{array}$ & $\begin{array}{c}\text { Body height } \\
(\mathbf{c m})\end{array}$ & $\begin{array}{c}\text { BM } \\
(\mathbf{k g})\end{array}$ & $\begin{array}{c}\text { BMI } \\
\mathbf{( k g} \cdot \mathbf{~ m}^{-2} \mathbf{)}\end{array}$ \\
\hline$E T(n=12)$ & $22.33 \pm 1.44$ & $180.3 \pm 7.98$ & $76.84 \pm 14.40$ & $23.58 \pm 3.82$ \\
$\operatorname{CON}(n=12)$ & $22.83 \pm 1.27$ & $177.8 \pm 5.72$ & $73.38 \pm 10.54$ & $23.14 \pm 2.48$ \\
\hline
\end{tabular}

BM, body mass. There were no significant differences $(P>0.2)$.

\section{Incremental exercise test}

In order to examine pre- and post-training level of physical fitness, ET group $(\mathrm{n}=12)$ performed a maximal incremental exercise test on a cycle ergometer. After a 6-min rest sitting on the cycle ergometer, the test started at $30 \mathrm{~W}$ and the power output was then gradually increased by $30 \mathrm{~W}$ every $3 \mathrm{~min}$. When the subjects could not continue cycling at the required pedaling rate $\left(60 \mathrm{rev} \cdot \mathrm{min}^{-1}\right)$ and power output, the test was stopped. Incremental exercise test was conducted on Ergometrics $800 \mathrm{~S}$ cycle ergometer (Ergoline GmbH, Bitz, Germany) and during the test, the peak oxygen uptake $\left(\mathrm{VO}_{2 \text { peak }}\right)$ was measured using breath-by-breath gas analysis system (Oxycon Champion Jaeger, Mijnhardt B.V., Bunnik, Netherlands) as previously described by Zoladz et al. (1995). Moreover, a blood samples were taken at rest and at the end of every $3 \mathrm{~min}$ stage to determine lactate threshold (LT), that was defined as the power output $\left(\mathrm{PO}_{\mathrm{LT}}\right)$ above which plasma lactate displayed a continuous increase of at least $0.5 \mathrm{mmol} \cdot 1^{-1}$ during each subsequent stage of incremental test (Majerczak et al. 2012, Zoladz et al. 1995, 2013). Heart rate was continuously monitored and recorded throughout all exercise test (Polar S810, Polar Electro Oy, Kempele, Finland).

\section{Maximal voluntary contraction (MVC)}

Maximal voluntary isometric contraction (MVC) of the knee extensor muscle was performed in ET group on a prototype chair equipped with a strain gauge as described in detail in a previous paper (Zoladz et al. 2012). Briefly, the subjects were tested in a seated position with their pelvis and thigh stabilized to minimize unwanted movements. Hips and knees were fixed at $90^{\circ}$ of flexion. Inextensible strap was placed around the subject's ankle at the front of the chair and attached to the strain gauge at the back of the chair. During forceful isometric contraction against the strap, the output signal from the strain gauge was amplified and converted from analog to digital and monitored and stored on a computer by a purpose made software.

MVC testing session began with standard warm-up procedure including bicycling on the stationary ergometer, freely chosen lower extremity exercises as well as short submaximal isometric contraction after positioning on the testing chair. During measurement of the MVC of the knee extensors, the subjects were asked to push as forcefully as possible for about $3 \mathrm{~s}$ against the strap. This measurement was repeated three times with each leg with 2 min break in between and the MVC was determined as an average from the two trials that yielded the largest value for each leg. In addition to MVC data, the torque was calculated by multiplying the MVC by the lever arm that was kept constant before and after the training program.

Time to fatigue at $50 \%$ of maximal voluntary contraction (TTF $50 \% \mathrm{MVC}$ )

After completing the last MVC trial a minimum 5 min of rest was applied and then the subjects underwent the measurement of TTF $50 \%$ MVC for each leg with at least $5 \mathrm{~min}$ rest in between. In this test, the subjects were instructed to maintain a target force level $(50 \%$ MVC) until maximal exhaustion. The target as well as instantaneous force level were visibly displayed on the monitor screen in front of the subjects. TTF $50 \% \mathrm{MVC}$ was measured in seconds from the onset of the test (subjects reached the target force in 1-2 s) to the point when the subjects were unable to maintain the required force level for 3 consecutive seconds. TTF $50 \% \mathrm{MVC}$ was expressed as an average of two measurements (right and left leg). This time is regarded as an index of local muscular endurance (Kraemer et al. 2006).

\section{Endurance training program}

Half of the volunteers (ET group), i.e. 12 subjects, underwent a supervised endurance training program on a cycle ergometer (Monark $874 \mathrm{E}$, Monark 
Exercise AB, Vansbro, Sweden), four times a week for 20 weeks. The training program started at the beginning of December and ended in the middle of March. Training consisted of two different exercise protocols (each lasting $40 \mathrm{~min}$ ): a moderate-intensity continuous cycling (CC) and a high-intensity intermittent cycling (IC). CC was performed at the power output corresponding to $90 \%$ of the previously determined lactate threshold ( $90 \%$ LT), whereas IC consisted of 6 min of unloaded cycling followed by a $3 \mathrm{~min}$ exercise bout at the power output corresponding to $50 \% \Delta$ repeated four times and finished with $4 \mathrm{~min}$ of unloaded cycling. The power output corresponding to $50 \% \Delta$ was calculated as the difference between the power output reached at $\mathrm{Vo}_{2 \text { peak }}\left(\mathrm{PO}_{\max }\right)$ and the power output obtained at the LT $\left(\mathrm{PO}_{\mathrm{LT}}\right)[50 \% \Delta=$ $\left.\mathrm{PO}_{\mathrm{LT}}+0.5\left(\mathrm{PO}_{\max }-\mathrm{PO}_{\mathrm{LT}}\right)\right]$. To maintain an adequate training stimulus, the power output was adjusted after first 5 weeks of training and then after each of the five weeks period of the study. From the beginning of the $6^{\text {th }}$ week until the end of the $10^{\text {th }}$ week, the unloaded cycling in the IC sessions was replaced by cycling at the $90 \%$ LT. During the next five weeks, the power output corresponding to $90 \% \mathrm{LT}$ was increased by $5 \%$ both in $\mathrm{CC}$ and IC protocols (from week $11^{\text {th }}$ to $15^{\text {th }}$ ) and by $15 \%$ during the last five weeks of the training program (from week $16^{\text {th }}$ to $20^{\text {th }}$ ). The $\mathrm{CC}$ was performed on Tuesdays and Fridays, and IC on Mondays and Thursdays. Each training session was monitored using a heart rate monitor (Polar S810, Polar Electro Oy, Kempele, Finland) and supervised by one of the authors. The average training heart rate during the 20 week training period amounted to $125 \pm 10 \mathrm{bt} \cdot \mathrm{min}^{-1}(67 \%$ of maximum heart rate) and $133 \pm 9 \mathrm{bt} \cdot \mathrm{min}^{-1}(71 \%$ of maximum heart rate), for $\mathrm{CC}$ and IC exercise protocols respectively. Moreover, the session RPE ratings was taken within 15 min after the completion of each exercise bout. During the training period subjects were asked to keep their normal mixed diet and to avoid taking any nutritional supplements or consuming alcohol.

\section{Blood collection}

Fasting (overnight) blood samples were taken at rest between 7:30 and 8:30 a.m. from both group of subjects (ET and CON). Samples were drawn from the antecubital vein. Blood for hemoglobin $(\mathrm{Hb})$, erythrocyte (E), and leukocyte (L) counts as well as for hematocrit value (Hct) was collected into plain tubes containing EDTA. Blood for serum sodium $\left(\mathrm{Na}^{+}\right)$, potassium $\left(\mathrm{K}^{+}\right)$, creatinine $(\mathrm{Cr})$, albumin $(\mathrm{Alb}), \mathrm{T}, \mathrm{C}$ and $\mathrm{SHBG}$ concentrations was collected into plain tubes and left to clot for a minimum of $30 \mathrm{~min}$ at room temperature and then centrifuged at $4000 \mathrm{rev} \cdot \mathrm{min}^{-1}$ for $5 \mathrm{~min}$. Serum was stored at $-80^{\circ} \mathrm{C}$ until analysis.

Moreover, in order to determine the lactate threshold (LT) in ET subjects, the blood samples were also collected during incremental exercise test (see above) via an Abbot Int-Catheter, Ireland (18G/1.2 $\times$ $45 \mathrm{~mm}$ ) inserted into an antecubital vein and connected to an extension set using a "T" Adapter (SL Abbot, Ireland) (the length of the tube was $10 \mathrm{~cm}$ ). The blood samples $(0.5 \mathrm{ml}$ each) were placed in $1.8 \mathrm{ml}$ Eppendorf tubes containing $1 \mathrm{mg}$ ammonium oxalate and $5 \mathrm{mg}$ sodium fluoride, mixed for $20 \mathrm{~s}$ and then centrifuged at $4000 \mathrm{rev} \cdot \mathrm{min}^{-1}$ for $4 \mathrm{~min}$. The obtained samples of plasma were stored at $-80{ }^{\circ} \mathrm{C}$ until analysis.

\section{Blood analysis}

Hemoglobin, hematocrit, erythrocyte and leukocyte count were analyzed by optical method with an Advia 2120 automated hematological analyzer (Siemens Healthcare Diagnostics, Tarrytown, NY, USA). Serum sodium, potassium and creatinine concentrations were determined according to the manufacturer's protocol using the Cobas c501 analyzer (Roche Diagnostics, Mannheim, Germany). Plasma lactate concentration was measured using an automatic analyzer Vitros 250 Dry Chemistry System, Kodak (Rochester, NY, USA). Moreover, in order to further calculate the fT, serum (Alb) was quantified by capillary electrophoresis (Minicap, Sebia, Lisses, France).

All hormone measurements were performed in duplicate and serum T, C and SHBG were determined by electrochemiluminescence immunoassay using the Cobas e411 analyzer (Roche Diagnostics, Mannheim, Germany) with detection limits of $0.09,1.0$ and $0.8 \mathrm{nmol} \cdot 1^{-1}$ for $\mathrm{T}, \mathrm{C}$ and $\mathrm{SHBG}$, respectively. The intra and interassay coefficient of variation (CV) for these assays was $3.4 \%$ and $5.9 \%, 1.2 \%$ and $1.6 \%, 2.4 \%$ and $3.7 \%$ for T, C and SHBG respectively. Moreover, fT was calculated using the assumption-free empirical equations (Ly and Handelsman 2005), as it was showed that this method gives fT concentrations closer to the precise laboratory measurements (equilibrium dialysis and centrifugal ultrafiltration) than other commonly used standard calculated fT estimates (Ly and Handelsman 2005). 


\section{Statistical analysis}

In this study, non-parametric tests were employed because of the relatively small sample size $(\mathrm{n}=12$ in each group of subjects). With this amount of data points, it is not possible to reliably verify the assumption of normality that is needed for an application of standard parametric tests. It should be also noted that the use of non-parametric tests is a much more conservative approach to testing the significance of the differences than parametric testing. From these reasons, intragroup comparisons were performed with the use of the Wilcoxon signed rank test and intergroup comparisons with the use of the Mann-Whitney U test. The correlations between hormonal and TTF $50 \%$ MVC data were evaluated using the Spearman's correlation coefficient. The significance level was set at $P<0.05$ and all data are presented as mean \pm SD. The analyses were performed using STATISTICA software, version 10 (StatSoft, Inc., 2011, www.statsoft.com).

\section{Results}

Physical characteristics of the subjects

The subjects from ET and CON group did not differ significantly in mean age, body height, BM and BMI at inclusion to the study (Table 1). 20 weeks of endurance training program did not change significantly $\mathrm{BM}$ and BMI in the ET group $(76.8 \pm 14.4$ vs. $77.1 \pm 12.8 \mathrm{~kg}$ and $23.58 \pm 3.82$ vs. $23.67 \pm 3.41 \mathrm{~kg} \cdot \mathrm{m}^{-2}$ for pre- and post-training $\mathrm{BM}$ and $\mathrm{BMI}$, respectively, $P>0.7$ ). Similarly, the same period of time did not change BM and $\mathrm{BMI}$ in the CON group $(73.4 \pm 10.5$ vs. $73.5 \pm 11.0 \mathrm{~kg}$ and $23.14 \pm 2.48$ vs. $23.17 \pm 2.69 \mathrm{~kg} \cdot \mathrm{m}^{-2}$ for before and after control period BM and BMI, respectively, $P>0.6$ ). As it could be expected, body mass and BMI measured after these 20 weeks of intervention were not different between ET and CON groups and changes in these two variables $(\triangle \mathrm{BM}$ and $\triangle \mathrm{BMI})$ were also non-significant.

\section{Blood morphology and biochemistry}

Selected blood morphology and biochemistry parameters are given in Table 2. Besides significantly higher pre-training E concentration in the ET group, there were no other significant differences $(P>0.05)$ between ET and CON group at the beginning as well as at the end of the study (i.e. after 20 weeks of the endurance training in ET subjects and after 20 weeks of control period in CON subjects).

Table 2. Basic blood variable at the beginning of the intervention period in both groups $(E T, n=12$ and $C O N, n=12)$.

\begin{tabular}{|c|c|c|c|c|c|c|c|c|}
\hline & $\begin{array}{l}\text { Het } \\
(1 / l)\end{array}$ & $\begin{array}{c}\mathbf{H b} \\
\left(\mathrm{g} \cdot \mathrm{dl}^{-1}\right)\end{array}$ & $\begin{array}{c}\mathbf{L} \\
\left(\times 10^{9} \cdot \mathrm{I}^{-1}\right)\end{array}$ & $\begin{array}{c}E \\
\left(\times 10^{12} \cdot 1^{-1}\right)\end{array}$ & $\begin{array}{c}\mathrm{Na}^{+} \\
\left(\mathrm{mmol} \cdot \mathrm{l}^{-1}\right)\end{array}$ & $\begin{array}{c}\mathrm{K}^{+} \\
\left(\mathrm{mmol} \cdot \mathrm{l}^{-1}\right)\end{array}$ & $\begin{array}{c}\mathrm{Cr} \\
\left(\mu \mathrm{mol} \cdot \mathrm{l}^{-1}\right)\end{array}$ & $\begin{array}{c}\text { Alb } \\
\left(\mathrm{g} \cdot \mathrm{I}^{-1}\right)\end{array}$ \\
\hline ET & $0.47 \pm 0.23$ & $16.0 \pm 0.9$ & $6.00 \pm 0.87$ & $5.42 \pm 0.30$ & $140.1 \pm 1.8$ & $4.34 \pm 0.35$ & $90.2 \pm 8.1$ & $44.6 \pm 2.1$ \\
\hline$C O N$ & $0.45 \pm 0.20$ & $15.3 \pm 0.8$ & $5.49 \pm 0.81$ & $5.06 \pm 0.22$ & $140.1 \pm 1.2$ & $4.39 \pm 0.33$ & $89.0 \pm 11.9$ & $46.0 \pm 2.1$ \\
\hline$P$ level & 0.089 & 0.052 & 0.178 & 0.002 & 0.410 & 0.671 & 0.976 & 0.128 \\
\hline
\end{tabular}

Hct, hematocrit value; $\mathrm{Hb}$, hemoglobin concentration; $\mathrm{E}$, erythrocyte count; $\mathrm{L}$, leukocyte count; $\mathrm{Na}^{+}$, sodium concentration; $\mathrm{K}^{+}$, potassium concentration; $\mathrm{Cr}$, creatinine concentration; Alb, albumin concentration.

\section{Exercise capacity}

Before training the mean $\mathrm{VO}_{2 \text { peak }}$ was $3198 \pm 458 \mathrm{ml} \cdot \mathrm{min}^{-1}\left(42.27 \pm 5.69 \mathrm{ml} \cdot \mathrm{kg}^{-1} \cdot \mathrm{min}^{-1}\right), \mathrm{PO}_{\mathrm{LT}}$ amounted to $120 \pm 29 \mathrm{~W}$ and $\mathrm{PO}_{\max }$ to $232 \pm 35 \mathrm{~W}$ in ET group. Although, 20 weeks of endurance training did not change $\mathrm{VO}_{2 \text { peak }}(P>0.05)$, the $\mathrm{PO}_{\mathrm{LT}}$ and $\mathrm{PO}_{\max }$ increased significantly by $19 \%(P=0.01)$ and by $14 \%$ $(P=0.003)$, respectively. Power output reached at $\mathrm{VO}_{2 \text { peak }}$ was also increased when expressed in relative terms $\left(3.1 \pm 0.4 \mathrm{~W} \cdot \mathrm{kg}^{-1}\right.$ before and $3.5 \pm 0.3 \mathrm{~W} \cdot \mathrm{kg}^{-1}$ after the training, $P=0.002$ ).

\section{Isometric strength and endurance}

Isometric strength and endurance of the knee extensor muscles were significantly augmented after 20 weeks of endurance exercise training on a cycle ergometer. MVC increased from $672 \pm 117$ to $732 \pm 126 \mathrm{~N}$ (before and after training respectively, $P=0.002$ ), torque form $202 \pm 35$ to $220 \pm 38 \mathrm{Nm}$ (before and after training respectively, $P=0.002$ ) and TTF $50 \% \mathrm{MVC}$ from $61 \pm 19$ to $74 \pm 25 \mathrm{~s}$ (before and after training respectively, $P=0.004$ ). Additionally, it was found that change in MVC ( $\triangle \mathrm{MVC})$ after endurance training was positively correlated with change in $\mathrm{PO}_{\max }\left(\Delta \mathrm{PO}_{\max }\right)$ 
$($ r Spearman $=0.68, P=0.014)$.

\section{Hormonal responses}

Hormone concentrations for both groups are given in Table 3. Endurance training in ET group did not lead to basal changes in $\mathrm{T}$, fT and SHBG concentrations, but significantly reduced basal $\mathrm{C}$ concentration $(P=0.006$, Fig. 1A). The decreased basal $\mathrm{C}$ concentration after training in ET group was clearly observed in a majority of subjects (Fig. 1B). This substantial drop in $\mathrm{C}$ concentration resulted in significantly higher $\mathrm{T} / \mathrm{C}$ and $\mathrm{fT} / \mathrm{C}$ ratio after 20 weeks of the endurance training.
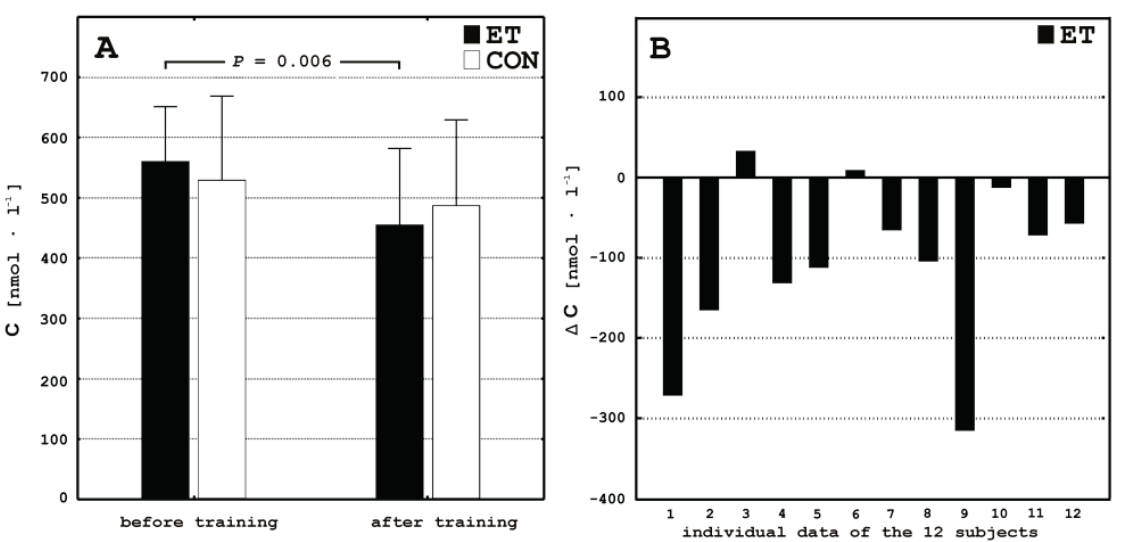

Fig. 1. Basal mean serum cortisol concentrations before and after 20 weeks of the study period in ET and CON group (A) and individual changes in basal C concentration $(\Delta C)$ in each of the 12 subjects from ET group in response to endurance training (B).
On the other hand, 20 weeks of control period in CON group did not alter significantly any of the hormone concentrations determined in this study (Table 3 and Fig. 1A).

Correlations between muscle performance and hormonal variables

There was a significant positive correlation between the change in $\mathrm{C}$ concentration $(\Delta \mathrm{C})$ and change in TTF $50 \%$ MVC ( $\triangle$ TTF $50 \%$ MVC) (Fig. 2). As it could be expected a negative correlations were also found between the changes in $\mathrm{T} / \mathrm{C}$ ratio and $\mathrm{fT} / \mathrm{C}$ ratio $(\Delta \mathrm{T} / \mathrm{C}$ and $\triangle \mathrm{fT} / \mathrm{C}$ ratio, respectively) and $\Delta \mathrm{TTF} \quad 50 \% \quad \mathrm{MVC}$ (Fig. 3A,B). Moreover, there was also a trend for negative correlations between change in MVC and change in $\mathrm{fT} / \mathrm{C}$ ratio, although this correlation did not reach statistical significance (r Spearman $=-0.48, P=0.11$ ).

\section{Discussion}

The main and original finding of this study is that the long-term endurance training program of moderate intensity led to an increase in muscle strength (9\% increase in MVC) and local muscle endurance (21\% increase in TTF $50 \%$ MVC), what was accompanied by a significant decrease in $\mathrm{C}$ concentration (Fig. 1) and a significant increase in $\mathrm{T} / \mathrm{C}$ and $\mathrm{fT} / \mathrm{C}$ ratio in ET group (Table 3). Interestingly, however, we have observed that training induced change in TTF $50 \%$ MVC was positively correlated with change in $\mathrm{C}$ concentration (Fig. 2) and negatively correlated with changes in $\mathrm{T} / \mathrm{C}$ and $\mathrm{fT} / \mathrm{C}$ ratio (Fig. 3). From these findings, one may conclude that skeletal muscle performance was more improved in subjects with the smallest changes in hormonal variable, i.e. no or only small drop in $\mathrm{C}$ concentration and the least increase in $\mathrm{T} / \mathrm{C}$ and $\mathrm{fT} / \mathrm{C}$ ratio (Figs 2 and 3 ).

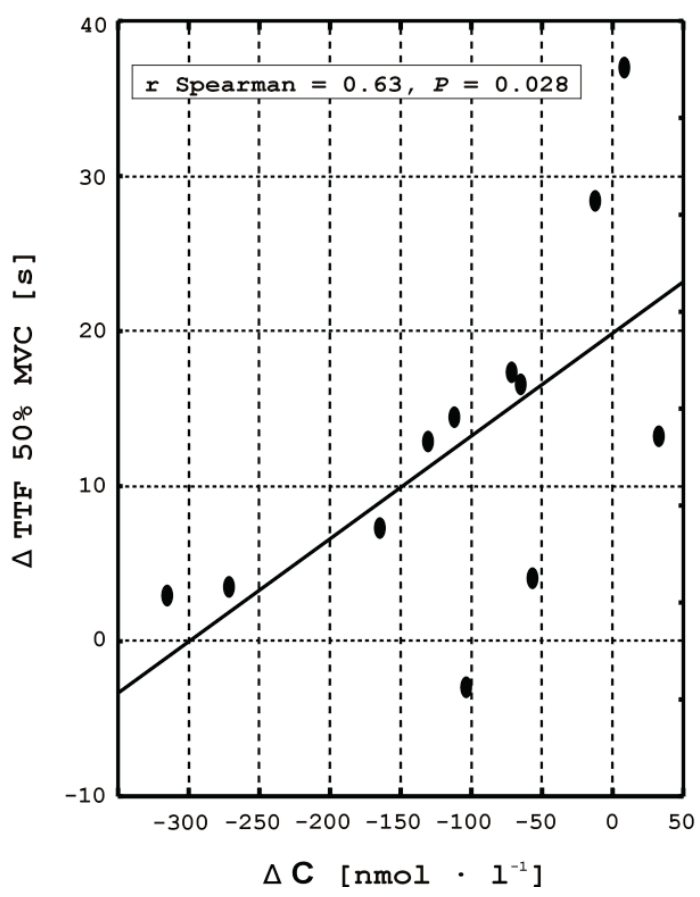

Fig. 2. Correlation between the change in TTF $50 \% \mathrm{MVC}$ $(\Delta \mathrm{TTF} 50 \% \mathrm{MVC}$ ) and change in $\mathrm{C}$ concentration $(\Delta \mathrm{C})$ in ET group. 
Table 3. Hormonal data in ET and CON groups before and after 20 weeks of the intervention period.

\begin{tabular}{|c|c|c|c|c|}
\hline & Training & ET $(n=12)$ & $\operatorname{CON}(n=12)$ & $\begin{array}{c}\text { P level } \\
\text { ET vs. CON }\end{array}$ \\
\hline \multirow[t]{3}{*}{$T\left(\mathrm{nmol} \cdot l^{-1}\right)$} & before & $20.25 \pm 5.01$ & $21.09 \pm 4.08$ & 0.630 \\
\hline & after & $20.54 \pm 4.19$ & $20.60 \pm 4.71$ & 0.755 \\
\hline & P level & 0.754 & 0.530 & \\
\hline \multirow[t]{3}{*}{$f T\left(p m o l \cdot l^{-1}\right)$} & before & $344 \pm 70$ & $362 \pm 61$ & 0.630 \\
\hline & after & $345 \pm 60$ & $349 \pm 80$ & 0.630 \\
\hline & P level & 0.814 & 0.480 & \\
\hline \multirow[t]{3}{*}{$S H B G\left(\mathrm{nmol} \cdot l^{-1}\right)$} & before & $29.46 \pm 13.07$ & $29.99 \pm 14.61$ & 0.932 \\
\hline & after & $32.54 \pm 15.01$ & $31.49 \pm 10.37$ & 0.799 \\
\hline & P level & 0.084 & 0.136 & \\
\hline \multirow[t]{3}{*}{$C\left(\mathrm{nmol} \cdot l^{-1}\right)$} & before & $560 \pm 91$ & $529 \pm 140$ & 0.410 \\
\hline & after & $455 \pm 127$ & $487 \pm 143$ & 0.551 \\
\hline & P level & 0.006 & 0.530 & \\
\hline \multirow[t]{3}{*}{$T / C\left(\times 10^{3}\right)$} & before & $37.03 \pm 10.63$ & $41.95 \pm 10.97$ & 0.291 \\
\hline & after & $47.61 \pm 12.55$ & $45.27 \pm 15.33$ & 0.551 \\
\hline & P level & 0.010 & 0.638 & \\
\hline \multirow[t]{3}{*}{$f T / C\left(\times 10^{-3}\right)$} & before & $0.63 \pm 0.17$ & $0.72 \pm 0.19$ & 0.143 \\
\hline & after & $0.81 \pm 0.24$ & $0.76 \pm 0.24$ & 0.755 \\
\hline & $P$ level & 0.015 & 0.754 & \\
\hline
\end{tabular}

$\mathrm{T}$, testosterone concentration; $\mathrm{fT}$, free testosterone concentration; SHGB, sex hormone-binding globulin concentration; $\mathrm{C}$, cortisol concentration; T/C, testosterone to cortisol ratio; $\mathrm{FT} / \mathrm{C}$, free testosterone to cortisol ratio.
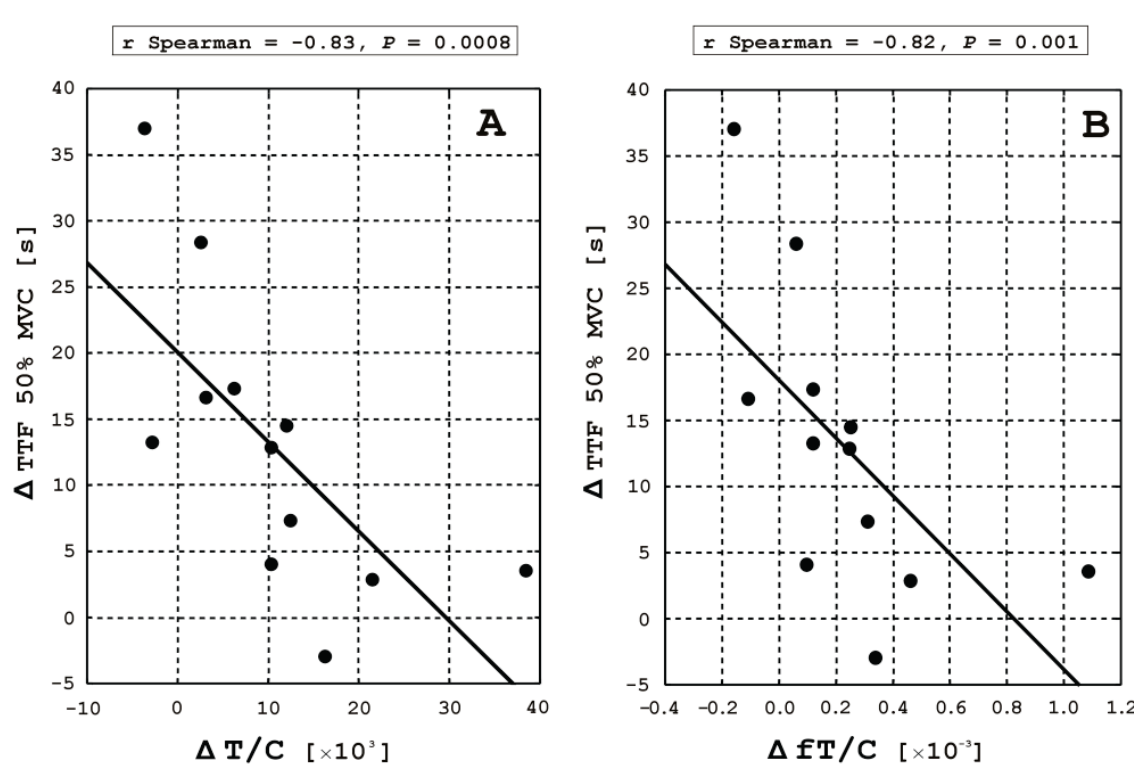

Fig. 3. Correlations between the changes in TTF $50 \%$ MVC ( $\triangle T$ TTF $50 \%$ $\mathrm{MVC}$ ) and changes in $\mathrm{T} / \mathrm{C}$ ratio $(\Delta \mathrm{T} / \mathrm{C})$ (A) and $\mathrm{fT} / \mathrm{C}$ ratio $(\Delta \mathrm{TT} / \mathrm{C})(\mathrm{B})$ in $\mathrm{ET}$ group.

Our data demonstrating increased muscle strength and local muscular endurance confirms previously reported suggestions (Bell et al. 2000,
Grandys et al. 2008) that endurance cycling training may improve muscular strength performance. Although, the exact mechanism(s) of this improvement in our subjects 
remains unknown, it is well accepted that muscle strength could be enhanced due to increase in muscle mass and/or neural control of movement (e.g. in increase in the number of motor unit recruited or greater motoneuron firing frequency) (Sale 1988, Zoladz et al. 2012). The lack of changes observed in BM and BMI after 20 weeks of endurance training could reflect hidden changes in body composition in ET group, i.e. decrease in body fat and increase in muscle mass that may be responsible for the observed improvement in muscle strength performance. We have also shown that this improvement is important for the endurance cycling performance, because change in MVC was correlated to change in $\mathrm{PO}_{\max }$ (see Results). However, to our best knowledge, there is no study showing that the greater improvement in muscle performance was found in the subjects with the smallest changes in $\mathrm{C}$ concentration (i.e. smallest decrease) and $\mathrm{T} / \mathrm{C}$ and $\mathrm{fT} / \mathrm{C}$ ratio (i.e. smallest increase). In previously published studies, where changes in basal $\mathrm{T}, \mathrm{C}$ and their ratio were linked with muscle strength improvement (usually strength training programs), the opposite findings were presented and an increase in muscle strength performance was related to an increase in $\mathrm{T} / \mathrm{C}$ ratio and a decrease in $\mathrm{C}$ concentration (Hakkinen et al. 1985, Staron et al. 1994). However, we are inclined to think that basal changes in anabolic-catabolic hormone balance during exercise training programs are above all an outcome of the applied training load (Flynn et al. 1994, Grandys et al. 2011, Kraemer et al. 2004) and have rather little influence on the skeletal muscle performance (Grandys et al. 2012). From this point of view the observed decrease in basal $\mathrm{C}$ concentration in this study as a consequence of 20 weeks of endurance cycling training is very intriguing.

Endurance training programs generally result in no change (Bresciani et al. 2011, Grandys et al. 2008, Lehmann et al. 1993) or an increase in basal $\mathrm{C}$ concentration as a consequence of increased physiological stress related to high training loads (Hoogeveen and Zonderland 1996, Kirwan et al. 1988, Seidman et al. 1990). To our best knowledge, endurance training-induced decrease in serum basal $\mathrm{C}$ concentration in previously untrained men was only once reported (Wheeler et al. 1991), but this pattern of response was often demonstrated in endurance trained elite athletes who were exposed to excessive training loads (Banfi et al. 1993, Lucia et al. 2001) or diagnosed as overtrained (Lehmann et al. 1992, Snyder et al. 1995). The decreased basal $\mathrm{C}$ concentration after prolonged period of heavy load training could be a result of two probably interdependent mechanisms that have been implicated in the literature in training-induced alteration in the hypothalamic-pituitary-adrenal axis (HPA): decreased pituitary sensitivity to $\mathrm{C}$ negative feedback (Duclos $e t a l$. 2001) and a reduced adrenal responsiveness to ACTH stimulation (Lehmann et al. 1993, Wittert et al. 1996).

Despite relatively moderate training intensity used in this study ( $\sim 85 \%$ of total training time was performed at the intensity below LT) we cannot rule out the possibility of overreaching (for discussion of the overreaching and its connection to overtraining see Meeusen et al. 2013) after nearly 5 months of progressively increasing training loads, at least in these subjects from ET group that revealed the smallest training-induced increase in MVC and TTF $50 \%$ MVC. An individual analysis of our data and the positive correlation between the changes in $\mathrm{C}$ concentration and the changes in TTF $50 \%$ MVC (Fig. 2) revealed that subjects with the greatest decrease in serum C concentration had the smallest increase in local muscular performance. On the other hand, the direct consequence of the overtraining syndrome and its main symptom, i.e. decline in physical fitness, was not present in any of the subjects. Conversely, our ET group increased their mean endurance performance during incremental exercise test and mean muscle strength performance (see Results). Similar findings were presented in the aforementioned paper by Wheeler et al. (1991), where a decrease in C concentration was accompanied by an increase in $\mathrm{Vo}_{2 \max }$. Moreover, decrease in basal $\mathrm{C}$ concentration that occurred concomitantly with significant improvement in strength performance in previously untrained men was also noted after resistance training programs (Arazi et al. 2013, Staron et al. 1994). These data suggest that decreased basal $\mathrm{C}$ concentration after training period cannot be interpreted as a reliable sign of overtraining syndrome, and what is more, there are also studies where basal C concentration did not change (Urhausen et al. 1998) or even increased (Barron et al. 1985) in overtrained subjects. Taking into account all these data, it seems that a large variability in the $\mathrm{C}$ response to training load and its relationship with exercise capacity depends on the specific time-point in the training-induced alteration of the HPA axis.

On the other hand, decreased $\mathrm{C}$ concentration, as it was present in our subjects after endurance training, also appear to have health related consequences. We may 
suggest that this adaptive hormonal response may bring benefits for cardiovascular health, since it was recently shown that dysregulation of the HPA axis and increased $\mathrm{C}$ concentration is related to higher risk of a cardiovascular event (Vogelzangs et al. 2010), probably due to suppression of the nitric oxide system (Liu et al. 2009) and endothelial dysfunction (Akaza et al. 2010) what accelerates the process of atherosclerosis. Moreover, unfavorable blood lipid profile that is related to higher C concentration (Reynolds et al. 2010), allow us to speculate that heavy endurance training resulting in increased $\mathrm{C}$ concentration may create a potential risk for vascular disease, whereas moderate intensity endurance training enhances so called "metabolic fitness" (Despres and Lamarche 1994) that is related to improved metabolic variables responsible for the cardiovascular risk.

In this study, the decreased $\mathrm{C}$ concentration in ET group resulted also in an increased $\mathrm{T} / \mathrm{C}$ and $\mathrm{fT} / \mathrm{C}$ ratio (there were no changes in $\mathrm{T}$ and $\mathrm{fT}$ concentrations). We are not aware of any studies that showed an increased $\mathrm{T} / \mathrm{C}$ and $\mathrm{fT} / \mathrm{C}$ ratio after endurance training program that can be attributed to the training effect per se and not to restoration of these indices as a result of decreased training loads after heavy training period (Banfi et al. 1993). In the studies, where strength or sprint training programs were employed, the enhanced anaboliccatabolic balance expressed as an increase in $\mathrm{T} / \mathrm{C}$ ratio was often observed (Farzad et al. 2011, Hakkinen et al. 1985), but in the endurance training programs usually no changes (Flynn et al. 1994, Grandys et al. 2009) or a decrease in $\mathrm{fT} / \mathrm{C}$ and $\mathrm{T} / \mathrm{C}$ ratio was demonstrated (Hoogeveen and Zonderland 1996, Seidman et al. 1990). Recently however, it was suggested (Grandys et al. 2009) that endurance training program can also lead to increase in this indices if the appropriate training load and sufficiently long training period is applied. In this study, we have observed an increase in $\mathrm{T} / \mathrm{C}$ and $\mathrm{fT} / \mathrm{C}$ ratios after 20-week long endurance training program, but as it was mentioned earlier, the decrease in $\mathrm{C}$ concentration was responsible for these changes. These findings demonstrate that training induced changes in $\mathrm{T} / \mathrm{C}$ and $\mathrm{fT} / \mathrm{C}$ should be used with caution in monitoring training loads. In some circumstances increased $\mathrm{T} / \mathrm{C}$ and $\mathrm{fT} / \mathrm{C}$ ratios may be inappropriately interpreted as a positive adaptation in anabolic-catabolic balance, whereas their changes resulted from markedly decreased $\mathrm{C}$ concentration without $\mathrm{T}$ and $\mathrm{fT}$ changes (as it was presented in this paper).

In conclusion, we have demonstrated that 20 weeks of endurance cycling training of moderate intensity increased maximal isometric muscle strength and local muscular endurance and that these changes were most likely beneficial for the observed improvement in the maximal power output generated during incremental cycling exercise test. Moreover, endurance training led to a decrease in basal $\mathrm{C}$ concentration and as a result to observed increase in $\mathrm{T} / \mathrm{C}$ and $\mathrm{fT} / \mathrm{C}$ ratios ( $\mathrm{T}$ and $\mathrm{fT}$ concentration did not change). The novel finding of this study is that the improvement in the muscle strength performance was reduced in subjects with the most noticeable decrease in basal cortisol concentration after endurance training. Because the other components of the HPA axis were not investigated in this study, we cannot fully explain this result. However, based on available data, it could be supposed that in some of our subjects the nearly 5 months of endurance training resulted in overreaching, that led to diminished $\mathrm{C}$ concentration and reduced gain in muscle strength performance. From this finding one may also infer that a decrease in $\mathrm{C}$ concentration might be indeed an early marker of overreaching, because this study shows that its decrease during endurance training precedes the decline in physical performance. However, in order to precisely establish the usefulness of cortisol measurement in diagnosis of overreaching, the further studies are needed to follow simultaneously the changes in muscle performance and $\mathrm{C}$ level during heavy training leading to overreaching.

\section{Conflict of Interest}

There is no conflict of interest.

\section{Acknowledgements}

This study was supported by European Union from the resources of the European Regional Development Fund under the Innovative Economy Programme (grant coordinated by JCET-UJ, No POIG.01.01.02-00-069/09).

\section{References}

AKAZA I, YOSHIMOTO T, TSUCHIYA K, HIRATA Y: Endothelial dysfunction associated with hypercortisolism is reversible in Cushing's syndrome. Endocr J 57: 245-252, 2010. 
ARAZI H, DAMIRCHI A, ASADI A: Age-related hormonal adaptations, muscle circumference and strength development with 8 weeks moderate intensity resistance training. Ann Endocrinol (Paris) 74: 30-35, 2013.

BANFI G, MARINELLI M, ROI GS, AGAPE V: Usefulness of free testosterone/cortisol ratio during a season of elite speed skating athletes. Int J Sports Med 14: 373-379, 1993.

BARRON JL, NOAKES TD, LEVY W, SMITH C, MILLAR RP: Hypothalamic dysfunction in overtrained athletes. $J$ Clin Endocrinol Metab 60: 803-806, 1985.

BELL GJ, SYROTUIK D, MARTIN TP, BURNHAM R, QUINNEY HA: Effect of concurrent strength and endurance training on skeletal muscle properties and hormone concentrations in humans. Eur J Appl Physiol 81: 418-427, 2000.

BRESCIANI G, CUEVAS MJ, MOLINERO O, ALMAR M, SUAY F, SALVADOR A, DE PAZ JA, MARQUEZ S, GONZALEZ-GALLEGO J: Signs of overload after an intensified training. Int J Sports Med 32: 338-343, 2011.

DE ARAUJO GG, GOBATTO CA, MARCOS-PEREIRA M, DOS REIS IG, VERLENGIA R: Interval versus continuous training with identical workload: physiological and aerobic capacity adaptations. Physiol Res 64 : 209-219, 2015.

DESPRES JP, LAMARCHE B: Low-intensity endurance exercise training, plasma lipoproteins and the risk of coronary heart disease. J Intern Med 236: 7-22, 1994.

DUCLOS M, CORCUFF JB, PEHOURCQ F, TABARIN A: Decreased pituitary sensitivity to glucocorticoids in endurance-trained men. Eur J Endocrinol 144: 363-368, 2001.

DUCLOS M, GOUARNE C, BONNEMAISON D: Acute and chronic effects of exercise on tissue sensitivity to glucocorticoids. J Appl Physiol 94: 869-875, 2003.

FARZAD B, GHARAKHANLOU R, AGHA-ALINEJAD H, CURBY DG, BAYATI M, BAHRAMINEJAD M, MAESTU J: Physiological and performance changes from the addition of a sprint interval program to wrestling training. J Strength Cond Res 25: 2392-2399, 2011.

FLYNN MG, PIZZA FX, BOONE JB JR, ANDRES FF, MICHAUD TA, RODRIGUEZ-ZAYAS JR: Indices of training stress during competitive running and swimming seasons. Int J Sports Med 15: 21-26, 1994.

GALBO H: The hormonal response to exercise. Diabetes Metab Rev 1: 385-408, 1986.

GRANDYS M, MAJERCZAK J, DUDA K, ZAPART-BUKOWSKA J, SZTEFKO K, ZOLADZ JA: The effect of endurance training on muscle strength in young, healthy men in relation to hormonal status. $J$ Physiol Pharmacol 59: 89-103, 2008.

GRANDYS M, MAJERCZAK J, DUDA K, ZAPART-BUKOWSKA J, KULPA J, ZOLADZ JA: Endurance training of moderate intensity increases testosterone concentration in young, healthy men. Int J Sports Med 30: 489-495, 2009.

GRANDYS M, MAJERCZAK J, ZAPART-BUKOWSKA J, KULPA J, ZOLADZ JA: Gonadal hormone status in highly trained sprinters and in untrained men. J Strength Cond Res 25: 1079-1084, 2011.

GRANDYS M, MAJERCZAK J, KARASINSKI J, KULPA J, ZOLADZ JA: Skeletal muscle myosin heavy chain isoform content in relation to gonadal hormones and anabolic-catabolic balance in trained and untrained men. J Strength Cond Res 26: 3262-3269, 2012.

HAKKINEN K, PAKARINEN A, ALEN M, KOMI PV: Serum hormones during prolonged training of neuromuscular performance. Eur J Appl Physiol Occup Physiol 53: 287-293, 1985.

HILL EE, ZACK E, BATTAGLINI C, VIRU M, VIRU A, HACKNEY AC: Exercise and circulating cortisol levels: the intensity threshold effect. J Endocrinol Invest 31: 587-591, 2008.

HOOGEVEEN AR, ZONDERLAND ML: Relationships between testosterone, cortisol and performance in professional cyclists. Int J Sports Med 17: 423-428, 1996.

KIRWAN JP, COSTILL DL, FLYNN MG, MITCHELL JB, FINK WJ, NEUFER PD, HOUMARD JA: Physiological responses to successive days of intense training in competitive swimmers. Med Sci Sports Exerc 20: 255-259, 1988.

KRAEMER WJ, FRENCH DN, PAXTON NJ, HAKKINEN K, VOLEK JS, SEBASTIANELLI WJ, PUTUKIAN M, NEWTON RU, RUBIN MR, GOMEZ AL, VESCOVI JD, RATAMESS NA, FLECK SJ, LYNCH JM, 
KNUTTGEN HG: Changes in exercise performance and hormonal concentrations over a big ten soccer season in starters and nonstarters. $J$ Strength Cond Res 18: 121-128, 2004.

KRAEMER WJ, RATAMESS NA, FRY AC, FRENCH DN: Strength testing: development and evaluation of methodology. In: Physiological Assessment of Human Fitness. MAUD P, FOSTER C (eds), Human Kinetics, Champaign, IL, 2006, pp 119-150.

LEHMANN M, GASTMANN U, PETERSEN KG, BACHL N, SEIDEL A, KHALAF AN, FISCHER S, KEUL J: Training-overtraining: performance, and hormone levels, after a defined increase in training volume versus intensity in experienced middle- and long-distance runners. Br J Sports Med 26: 233-242, 1992.

LEHMANN M, KNIZIA K, GASTMANN U, PETERSEN KG, KHALAF AN, BAUER S, KERP L, KEUL J: Influence of 6-week, 6 days per week, training on pituitary function in recreational athletes. Br J Sports Med 27: 186-192, 1993.

LIU Y, MLADINOV D, PIETRUSZ JL, USA K, LIANG M: Glucocorticoid response elements and 11 betahydroxysteroid dehydrogenases in the regulation of endothelial nitric oxide synthase expression. Cardiovasc Res 81: 140-147, 2009.

LUCIA A, DIAZ B, HOYOS J, FERNANDEZ C, VILLA G, BANDRES F, CHICHARRO JL: Hormone levels of world class cyclists during the Tour of Spain stage race. Br J Sports Med 35: 424-430, 2001.

LUGER A, DEUSTER PA, KYLE SB, GALLUCCI WT, MONTGOMERY LC, GOLD PW, LORIAUX DL, CHROUSOS GP: Acute hypothalamic-pituitary-adrenal responses to the stress of treadmill exercise. Physiologic adaptations to physical training. N Engl J Med 316: 1309-1315, 1987.

LY LP, HANDELSMAN DJ: Empirical estimation of free testosterone from testosterone and sex hormone-binding globulin immunoassays. Eur J Endocrinol 152: 471-478, 2005.

MAJERCZAK J, KOROSTYNSKI M, NIECKARZ Z, SZKUTNIK Z, DUDA K, ZOLADZ JA: Endurance training decreases the non-linearity in the oxygen uptake-power output relationship in humans. Exp Physiol 97: 386-399, 2012.

MEEUSEN R, DUCLOS M, FOSTER C, FRY A, GLEESON M, NIEMAN D, RAGLIN J, RIETJENS G, STEINACKER J, URHAUSEN A: Prevention, diagnosis, and treatment of the overtraining syndrome: joint consensus statement of the European College of Sport Science and the American College of Sports Medicine. Med Sci Sports Exerc 45: 186-205, 2013.

O'LEARY CB, HACKNEY AC: Acute and chronic effects of resistance exercise on the testosterone and cortisol responses in obese males: a systematic review. Physiol Res 63: 693-704, 2014.

REYNOLDS RM, LABAD J, STRACHAN MW, BRAUN A, FOWKES FG, LEE AJ, FRIER BM, SECKL JR, WALKER BR, PRICE JF: Elevated fasting plasma cortisol is associated with ischemic heart disease and its risk factors in people with type 2 diabetes: the Edinburgh type 2 diabetes study. $J$ Clin Endocrinol Metab 95: 1602-1608, 2010.

SALE DG: Neural adaptation to resistance training. Med Sci Sports Exerc 20 (5 Suppl): S135-S145, 1988.

SCHAKMAN O, KALISTA S, BARBE C, LOUMAYE A, THISSEN JP: Glucocorticoid-induced skeletal muscle atrophy. Int J Biochem Cell Biol 45: 2163-2172, 2013.

SEIDMAN DS, DOLEV E, DEUSTER PA, BURSTEIN R, ARNON R, EPSTEIN Y: Androgenic response to longterm physical training in male subjects. Int J Sports Med 11: 421-424, 1990.

SNYDER AC, KUIPERS H, CHENG B, SERVAIS R, FRANSEN E: Overtraining following intensified training with normal muscle glycogen. Med Sci Sports Exerc 27: 1063-1070, 1995.

STARON RS, KARAPONDO DL, KRAEMER WJ, FRY AC, GORDON SE, FALKEL JE, HAGERMAN FC, HIKIDA RS: Skeletal muscle adaptations during early phase of heavy-resistance training in men and women. J Appl Physiol 76: 1247-1255, 1994.

URHAUSEN A, GABRIEL HH, KINDERMANN W: Impaired pituitary hormonal response to exhaustive exercise in overtrained endurance athletes. Med Sci Sports Exerc 30: 407-414, 1998.

VAN RAALTE DH, NOFRATE V, BUNCK MC, VAN IERSEL T, ELASSAISS SCHAAP J, NASSANDER UK, HEINE RJ, MARI A, DOKTER WH, DIAMANT M: Acute and 2-week exposure to prednisolone impair different aspects of beta-cell function in healthy men. Eur J Endocrinol 162: 729-735, 2010. 
VOGELZANGS N, BEEKMAN AT, MILANESCHI Y, BANDINELLI S, FERRUCCI L, PENNINX BW: Urinary cortisol and six-year risk of all-cause and cardiovascular mortality. J Clin Endocrinol Metab 95: 4959-4964, 2010.

WHEELER GD, SINGH M, PIERCE WD, EPLING WF, CUMMING DC: Endurance training decreases serum testosterone levels in men without change in luteinizing hormone pulsatile release. J Clin Endocrinol Metab 72: 422-425, 1991.

WITTERT GA, LIVESEY JH, ESPINER EA, DONALD RA: Adaptation of the hypothalamopituitary adrenal axis to chronic exercise stress in humans. Med Sci Sports Exerc 28: 1015-1019, 1996.

ZOLADZ JA, RADEMAKER AC, SARGEANT AJ: Non-linear relationship between $\mathrm{O}_{2}$ uptake and power output at high intensities of exercise in humans. J Physiol 488: 211-217, 1995.

ZOLADZ JA, SZKUTNIK Z, MAJERCZAK J, GRANDYS M, DUDA K, GRASSI B: Isometric strength training lowers the $\mathrm{O}_{2}$ cost of cycling during moderate-intensity exercise. Eur J Appl Physiol 112: 4151-4161, 2012.

ZOLADZ JA, GRASSI B, MAJERCZAK J, SZKUTNIK Z, KOROSTYNSKI M, KARASINSKI J, KILARSKI W, KORZENIEWSKI B: Training-induced acceleration of $\mathrm{O}_{2}$ uptake on-kinetics precedes muscle mitochondrial biogenesis in humans. Exp Physiol 98: 883-898, 2013. 